\title{
Issues Emerging: Thoughts on the Reflective Articles on Coronavirus (COVID-19) and African Archaeology
}

\author{
Shadreck Chirikure
}

Published online: 28 August 2020

(C) Springer Science+Business Media, LLC, part of Springer Nature 2020

\section{Introduction}

With a ragtag methodology shrouded in Eurocentrism, archaeology emerged out of western antiquarianism during the late nineteenth and early twentieth centuries. Since then, the discipline evolved into a professional and high-resolution tool for exploring the deep and recent histories of Africa and other places in previously unimagined ways. The five contributions in this forum unanimously applaud the discipline's utility in solving or, at the very least, highlighting the challenges facing contemporary African communities. The long-term perspective allows the discipline to infer climatic and pandemic conditions (Holl; Pfeiffer) prevailing thousands of years ago while its short-term outlook shows how people coped with and adjusted to shocks such as droughts and epidemics (Douglass; Ogundiran). COVID-19, the papers show, is not just an epidemicit is an economic, social, and political malaise (Thiaw). There is a high expectation that archaeology offers many possibilities for grappling with present challenges, including public health. However, archaeology, especially that practiced in Africa, often lacks skills and high-resolution tools, thereby frustrating even the most optimistic among archaeologists. The coloniality that is

\footnotetext{
S. Chirikure

Department of Archaeology, University of Cape Town, Cape Town, South Africa

S. Chirikure $(\bowtie)$

School of Archaeology, University of Oxford, Oxford, UK

e-mail: shadreck.chirikure@uct.ac.za
}

front and center of archaeology (Thiaw) prevents the application of local solutions to local problems (see also Douglass). High expectations associated with archaeology, therefore, remain aspirational (Chirikure et al. 2010), with little to no impacts on the communities that the discipline ought to empower and impact.

\section{Archaeology of Knowledge and Knowledge of Archaeology: Pandemics and Local Agency}

Arguably, archaeology continues to empower scholars to develop refined understandings of events that took place in the deep past. Archeological and environmental records are an aggregate of daily, episodic, and rare experiences, all sedimented into the landscape, oldest at the bottom and youngest atop (Chirikure 2020; Chirikure et al. 2012). Deposits set in abandoned settlements or naturally along waterways and other points on the landscape are repositories of cultural and ecological information vital for peering into the past. In North Africa, the adjacent areas of West Africa, and elsewhere, climate change, often comprised of cycles of dry and wet conditions, was accompanied by adaptations that made communities resilient (Holl). The increasing aridity associated with the desertification of the Sahara reduced the size of water bodies, but it stimulated innovations such as pastoralism. The Saharan Neolithic pastoralists of the Messak Plateau in southwest Libya, for example, were able to live sustainably in this ecologically stressed landscape (Holl). Archaeology is, however, limited in its tools to understand how these adaptive 
strategies evolved at the fine temporal scale. Often, time can only be averaged in big aggregates in these studies, making it impossible to distinguish events of different durations (Chirikure et al. 2012). The margins of error associated with even the most precise dating techniques cannot tease apart events that occurred seasonally, annually, or even on a decadal scale. Coarse as the resolution is, it cannot be disputed that humans were not passive in the face of challenges. Rather, part of being human involved identifying challenges and developing solutions as life unfolded. Just as the inhabitants of North Africa and contiguous areas to the south made cultural interventions such as long-term food storage to cope with changing climates (Holl), the global community is now faced with the challenges of managing and curtailing the problems of COVID-19. The effects of the pandemic may be there for the long term, tapering or increasing depending on the effectiveness of innovations mobilized to deal with it.

The history of diseases and how they interact with human and nonhuman hosts contains vital information on how bodies and humans developed genes and other abilities to deal with bacterial and virologic infections. Over the longue durée, connectivity resulted in people mixing genes and, in the process, spreading different strains of diseases (Pfeiffer). Geneticists dedicated to understanding the evolution of diseases have highlighted important information on tuberculosis. However, not many geneticists study this area, especially in Africa, where paleopathology is a poorly developed area. This limits our biological and cultural knowledge of how diseases evolved within communities and how they affected people and societies in the past (Pfeiffer). There is a severe lack of skills, interest, and equipment in paleopathology in Africa. Unlike in other regions of the world where graduates in medicine and biochemistry take up careers in paleopathology, such a phenomenon is rare in Africa outside of South Africa. And yet, many of the equipment used by biochemists and geneticists are the same ones needed for studying the human populations of the deep past.

In Africa, most archaeologists are trained as culture historians or as heritage managers without requisite tools, especially those from the sciences, to understand diseases and how they mutate over the long durée. Should all archaeology be about the application of hard science techniques to derive biological and cultural information about past and present communities? Perhaps not. However, without adequate tools and demonstration of the contribution of our discipline to contemporary challenges such as COVID-19, African archaeologists cannot sit at agenda-setting tables for governments and intergovernmental organizations in their respective countries (Chirikure 2014). It is therefore not by coincidence that none of the experts on pottery or stone tool typologies managed to sit on any $\mathrm{NGO}$, government, or intergovernment advisory body tackling COVID-19 and other diseases. And yet, the knowledge set in past biological, ecological, and cultural archives is fundamental for developing plans to combat diseases in the present and future (Holl; Pfeiffer). Archaeology, therefore, must shake off its antiquarian ancestry and be more relevant to the present. It is one thing to reconstruct knowledge of the past and another to apply that knowledge to improve strategies for managing contemporary epidemics. One of the strengths of archaeology is the long-term perspective, which provides generations worth of experience in tackling the challenges of an ever-shifting present and future. It is possible to develop collaborations with biochemists and pharmacologists to combine cultural with biological information to address contemporary diseases (Dandara et al. 2020; Thomford et al. 2015; Thomford et al. 2018). As archaeologists, we need to broaden our training to cut across disciplines that will widen the skills of a new generation of students beyond pottery or stone tool typologies. An effective way of achieving this is by collaborating with colleagues in health sciences and other faculties with equipment in the same universities. The knowledge of archaeology does not translate into relevance and the ability to tackle problems, but the archaeology of problem-solving knowledge does (Chirikure et al. 2017).

\section{COVID-19, African Communities, and Local Ways of Managing Pandemics-Examples from the Recent Past}

On most accounts, the modern world seems a bit different from the past with the increased connectivity between far-ranging regions. However, sometimes there is an inaccurate impression that the Africa of today-a continent suffering from cumulative effects of the slave trade, colonialism, and postcolonial ills such as corruption-always lacked solutions for its problems. The deep-time perspective of archaeology shows that various communities had inbuilt mechanisms to live 
with disruptions and uncertainties, including in public health. For example, the Yorùbá of West Africa were conscious of diseases and that those diseases often reached pandemic proportions. One such example is that of Pẹe, a disease of the respiratory system, which decimated the population of Oyọ-Ilé in 1831 (Ogundiran). Despite the devastation caused by the pandemic, the Yorùbá remained in their settlements and never abandoned them. They physically distanced the sick from the healthy by placing them in the sacred groves that became spaces for healing, for recovering, and for caring of the sick (Ogundiran). Sacred groves were places full of medicines too! Consequently, Yorùbá rural and urban planning was designed with inbuilt mechanisms that allowed the management of diseases - a source of uncertainty in everyday life. This was also possible because of a lack of division between nature and culture in Yorùbá and other African cosmologies.

Comparatively, the Yorùbá practice of managing pandemics in situ raises some interesting discussion points with examples highlighted by Gérard Chouin, whose work suggests the massive abandonment of settlements in West Africa at the beginning of the second plague pandemic of the fourteenth century (Chouin 2018; Green and Symes 2015). While the examples by Ogundiran and Chouin speak to continuity and change, the former raises the observation that humans were not always powerless in their response to pandemics and did not always resort to migration. The Shona of Zimbabwe also physically separated the sick from the healthy and cared for them in physical isolation. In most African ontologies, diseases were caused by many things - biological, spiritual, and cultural (Gelfand 1981). In some cases, cultural ceremonies were held to find spiritual cures to pestilences. Indeed, the rinderpest pandemic (cattle disease), which swept across sub-Saharan Africa between 1896 and 1898 and decimated cattle, caused untold suffering, but people remained within their homesteads (Mavhunga 2011; Mutowo 2001). Although rinderpest was a cattle disease, people devised ways of managing it, including looking for divine intervention. The Shona, for example, blamed the imposition of colonialism and alien ways of life for the pestilence (Van Onselen 1972). The effects of the rinderpest partly caused the First Chimurenga, a resistance movement against colonialism led by spirit mediums Nehanda and Kaguvi (Pitts 1978). With a great deal of variability in African responses to pandemics, how might archaeologists recover some of these behaviors and link them to pandemics in the past? Clearly, a 2-×-2-m excavation trench will not capture the full depth and breadth of this wide array of responses. The impermanence of strategies involving physical distancing by placing the sick and unwell in seclusion makes it challenging to identify such "ephemeral" behaviors archaeologically. However, settlement organizations that favor low-density urbanism were also meant to manage diseases and allowed the environment to recover, offering a better quality of life.

\section{Archaeology and Social Justice_Empowering Communities}

My colleagues and I have critiqued how unprepared and weak archaeology has been in responding to local African challenges (Chirikure et al. 2010). Although there are many reasons for this state of affair, perhaps the most important is that, during colonialism, African knowledge was marginalized, caricatured, and even banned (Mavhunga 2011). This created an artificial break between millennia of practices and the new ones brought by the European colonists. Colonial education gave Africans very little opportunity to look after themselves using their ancestral knowledge. Instead, it created the dependency of the colonized on the western ontology. This should force us to rethink the way we do archaeology, in the field or laboratory, and through publications. It is time to design projects with communities with the goal to cocreate knowledge with them and bring some of their knowledge into the mainstream. Nearly a decade ago, Douglass and colleagues established the Morombe Archaeological Project in the Vezo territories of coastal southwest Madagascar (Douglass). The project was developed with the aim of cocreating knowledge with the Vezo communities using the ways of ancestors (razana). Ancestors also represent experience and validation since they would have seen it all. A strong community component of the project has enabled Madagascan colleagues to continue with the research during this pandemic, without the physical presence of collaborators from North America and other places. This shows that we can entrust our local partners with the responsibility to initiate and implement research projects for the collective good. This is one way of correcting the centuries-old marginalization of this type of community in the name of "objective science." The community-centered research design must be allowed to challenge and 
complement archaeological interpretations, revise concepts, and make their mark on the knowledge outcome (Chirikure et al. 2017). It would be interesting to learn how the publications and interpretations are dealt with in the Morombe Archaeological Project. Furthermore, gone are the days when colonial archaeologists were hiding sites from communities fearing they would destroy them. This model by Douglass and her team must be followed and modified to achieve more with smaller budgets and enlisting the support of people on the ground for building knowledge that is informed by indigenous ontologies. This has the potentials to produce local knowledge useful for confronting the ills afflicting society such as climate change, pandemic outbreaks, rising socioeconomic inequality, and other threats.

A contrast to the Morombe experience is how a large section of the world responded to the herb treatment, Artemisia afra, developed in Madagascar. This timetested medicine (by the ancestors) is known to provide relief for symptoms of COVID-19, such as shortness of breath and diarrhea (Dandara et al. 2020). However, this caused quite some sharp differences of opinion with the World Health Organization (WHO) demanding rigorous tests before it can approve its use. Indeed, rigorous clinical testing for any new drug is vital. However, the WHO and UNESCO ought to have provided Madagascar with the resources and other relevant assistance needed to achieve those tests. As an organization set up to coordinate global wellness, the validation of knowledge everywhere, based on scientific principles, should have been one of the WHO's priorities, not shutting down ideas that do not conform to the status quo. Knowledge hosted by African communities can be helpful and must be tested so they can be brought into the mainstream through research (Ogundiran 2020). This can form the basis of collaborations between pharmacologists, archaeologists, and communities (Thomford et al. 2018). In that case, rather than shamelessly proposing to test vaccines developed in France on Africans (Thiaw), African medicines should be tested scientifically with the goal of repurposing them to alleviate the effects of COVID-19 and other diseases.

\section{Conclusion: Arising Matters}

That archaeology is a useful subject with the potential to remold society is beyond doubt. Indeed, its tools and methods have opened frontiers of learning vital for breaking the interruption brought by the colony and sustained by the postcolony. By focusing on knowledge of the ancestors (razana), knowledge of teranga, Ubuntu, and many other examples scattered across Africa, archaeological outcomes can be usefully deployed in the service of communities, thereby addressing the century-old crisis of relevance. Making archaeology more responsive to local needs is empowering, and allowing practitioners of local knowledge to play a role even without external partners is liberating. Archaeology is a science that is also understood by the communities we interact with. Archaeology not only reconstructs the past, but archaeology-thinking can also guide us in using the past to understand the present (Ogundiran 2020). In addition, the COVID-19 experience has stimulated thinking on how contemporary knowledge and awareness can finetune our conceptualization of the past and the questions we ask of that past, as well as to reorganize the knowledge production enterprise in transformative, forward-thinking ways.

Based on these richly provocative contributions, how can we make archaeology better? There is no one good way-rather, a multidimensional approach is required. There is a need to rethink and repurpose the curriculum and training to ensure we get relevant knowledge. This will place the discipline on the agenda-setting table to influence policy (Chirikure 2014). We need to either recruit geneticists, biochemists, and other scientists to work in archaeology or ensure that archaeologists based in Africa are trained in those fields. The culture history approach to archaeology is limited in that the knowledge so produced is not directly usable. A change in approach would create nuanced information on places such as Great Zimbabwe and others where we know little about how they managed diseases and pandemics (Pfeiffer). Finally, there is a need for archaeologists and related specialists to be guided by African voices and communities. Otherwise, the advocacy for "indigenous archaeology," "community archaeology," and "decolonial archaeology" is likely to remain mere rhetorical slogans if we are not prepared to make radical changes on the ground. Archaeologists must colead with communities or be led by the communities. Only time will tell whether these expectations will be fulfilled or not. Nevertheless, seeing where things once were and where they are now, there might be a reason to be cautiously optimistic, although the pace of change can be frustratingly slow! 


\section{References}

Chirikure, S. (2014). 'Where angels fear to tread': Ethics, commercial archaeology, and extractive industries in southern Africa. Azania: Archaeological Research in Africa, 49(2), 218-231.

Chirikure, A. (2020). Great Zimbabwe: Reclaiming a 'confiscated' past. London: Routledge.

Chirikure, S., Manyanga, M., Ndoro, W., \& Pwiti, G. (2010). Unfulfilled promises? Heritage management and community participation at some of Africa's cultural heritage sites. International Journal of Heritage Studies, 16(1-2), 30-44.

Chirikure, S., Manyanga, M., \& Pollard, A. M. (2012). When science alone is not enough: Radiocarbon timescales, history, ethnography and elite settlements in southern Africa. Journal of Social Archaeology, 12(3), 356-379.

Chirikure, S., Nyamushosho, R. T., Chimhundu, H., Dandara, C., Pamburai, H. H., \& Manyanga, M. (2017). Concept and knowledge revision in the post-colony: Mukwerera, the practice of asking for rain amongst the Shona of southern Africa. In M. Manyanga \& S. Chirikure (Eds.), Archives, objects, places and landscapes: Multidisciplinary approaches to decolonised Zimbabwean pasts (pp. 14-55). Langaa: Bamenda.

Chouin, G. (2018). Reflections on plague in African history (14th19th c.). Afriques. Débats, méthodes et terrains d'histoire. https://doi.org/10.4000/afriques.2228.

Dandara, C., Dzobo, K., \& Chirikure, S. (2020). COVID-19 pandemic and Africa: From the situation in Zimbabwe to a case for precision herbal medicine. Omics: A Journal of Integrative Biology. https://doi.org/10.1089/omi.2020.0099.
Gelfand, M. (1981). African customs in relation to preventative medicine. Central African Journal of Medicine, 27(1), 1-8.

Green, M. H., \& Symes, C. L. (2015). Pandemic disease in the medieval world: Rethinking the black death. Kalamazoo: Arc Humanities Press.

Mavhunga, C. C. (2011). Vermin beings: On pestiferous animals and human game. Social Text, $29(1$ (106)), 151-176.

Mutowo, M. K. (2001). Animal diseases and human populations in colonial Zimbabwe: The rinderpest epidemic of 18961898. Zambezia, 28(1), 1-22.

Ogundiran, A. (2020). On COVID-19 and matters arising. African Archaeological Review, AAR, 37(2), 179-183. https://doi. org/10.1007/s10437-020-09390-x.

Pitts, D. (1978). Rinderpest and rebellion in Southern Rhodesia. Journal of International and Comparative Studies, 8(1), 22 34.

Thomford, N. E., Dzobo, K., Chopera, D., Wonkam, A., Skelton, M., Blackhurst, D., Chirikure, S., \& Dandara, C. (2015). Pharmacogenomics implications of using herbal medicinal plants on African populations in health transition. Pharmaceuticals, 8(3), 637-663.

Thomford, N. E., Dzobo, K., Chimusa, E., Andrae-Marobela, K., Chirikure, S., Wonkam, A., \& Dandara, C. (2018). Personalized herbal medicine? A roadmap for convergence of herbal and precision medicine biomarker innovations. Omics: A Journal of Integrative Biology, 22(6), 375-391.

Van Onselen, C. (1972). Reactions to rinderpest in southern Africa 1896-97. Journal of African history, 13(3), 473-488.

Publisher's Note Springer Nature remains neutral with regard to jurisdictional claims in published maps and institutional affiliations. 